\title{
SPATIAL DISTRIBUTION OF TUNA LARVAE IN THE BANDA SEA WITH RELATION TO ITS CONSERVATION
}

\author{
Ahmad Romdon ${ }^{1,2 *}$, Muhammad Fadli, ${ }^{1,2}$, Yance Hehuwat ${ }^{1,2}$, La Pay ${ }^{1,2}$, Widhya Nugroho \\ Satrioajie $^{1,2}$ and Augy Syahailatua ${ }^{3}$ \\ ${ }^{1}$ Research Center for Deep-Sea, Indonesian Institute of Sciences (LIPI), Ambon, Indonesia \\ ${ }^{2}$ Center of Excellence for Tuna Resources Conservation (PUI-KST), Ambon, Indonesia \\ ${ }^{3}$ Research Center for Oceanography, Indonesian Institute of Sciences (LIPI), Jakarta, Indonesia \\ *Correspondence author: 〈ahma077@ lipi.go.id>
}

\begin{abstract}
Tuna is the single valuable export fishery commodity in Indonesia, and Banda Sea is one of the main tuna fishing ground which belongs to fisheries management area (FMA) 714. More recently, the northern part of the Banda Sea has been preserved for tuna conservation since January 2015. The reason for this restriction is due to a preliminary of tuna spawning ground was adopted based on the scientific finding. Although conservation area has been enacted, information on the distribution of tuna larvae as a key variable for establishing conservation area in the Banda Sea needs to be improved through scientific findings. This study aims to provide the information on the tuna larvae encompassing the spatial distribution and tuna larval development stage as an important input to establish tuna conservation area. Tuna larvae data collection were carried out from several onboard surveys for more than four decades. Those study consisted of 21 surveys by using three types of gears to collect tuna larvae. Total of 143 stations was sampled from these surveys and tuna larvae were found in 57 stations. The average length of larvae specimens was $7.36 \pm 0.33 \mathrm{~mm}$. In general, tuna larvae found in the Banda Sea were in the pre-flexion, flexion, and post-flexion stage and larvae in pre-flexion stage found in the nearshore area. We concluded that the result of this study confirmed the hypothesis that tuna might spawn in the Banda Sea. Therefore, to strengthen this finding, studies on tuna larvae should be conducted regularly to clarify properly that the Banda Sea is an important tuna conservation zone.
\end{abstract}

Keywords: Tuna larvae, Distribution, Banda Sea.

\section{INTRODUCTION}

Tuna (family Scombridae, tribe Thunnini) is the single important export fishery commodity in Indonesia and commodity with high economic value on the fishery market (Lehodey et al., 2018). Tuna has made a significant contribution to Indonesia and world fisheries productions, and Indonesia gradually became the first tuna production country since 2004 (Sunoko and Huang, 2014). However, issues of overfishing and illegal, unreported and unregulated fishing practices (IUUF) are still the major threat of national fish stock and its management.

Establishing a conservation area was proposed as a precautionary approach in addressing those issues particularly on sustaining spawning stocks. Starting in January 2015, Indonesia government through Ministry of Marine Affairs and Fisheries (MMAF) issued a regulation of MMAF regulation 4/2015 (Menteri 
Perikanan dan Kelautan, 2015) that manages temporary closure area in the Banda Sea is part of tuna management practices in the country. The Banda Sea plays an important role as a buffer of the oceanic communication between the Pacific and Indian Oceans (Syamsudin et al., 2010). The Banda Sea is known as one of Indonesian important fishing grounds of commercial fishes (Tapilatu et al., 2018). This regulation, relies on the finding that larva tuna is abundant in some areas in the Banda Sea. Therefore, that area claimed as the spawning and breeding ground of yellowfin tuna (Thunnus albacares). The relationship among fish larvae abundance and its distribution with marine protected inspected in some other related studies (López-Sanz et al., 2009; Hitchman et al., 2012).

Despite the fact that the regulation has been applied since early 2015, a review study on tuna ecology in the Banda Sea revealed that very limited argument supporting the idea that tuna larva exists in the Banda Sea (Satrioajie et al., 2018). Moreover, only one study supports the finding that tuna larva was found in some areas near to the Banda Islands (Wagiyo et al., 2012). This conservation is might controversial due to limited studies, particularly major gap of the finding on presence tuna larva presence in the Banda Sea. This study aims to synthesize the information on the tuna larvae encompassing the spatial distribution and tuna larval development stage by compiling all tuna studies that were done in the Banda Sea over four decades. The finding will be significantly contributed to a better understanding of the role of Banda Sea for tuna conservation area.

\section{MATERIALS AND METHODS}

\section{Study sites and times}

Tuna (Thunnini) larvae distribution data were reanalyzed from several surveys that previously carried out in the Banda Sea. In total there are 21 surveys over four decades, starting from 1984 to May 2018. Tuna larva survey was first conducted in August 1984 and February-March 1985 (Soewito and Schalk, 1990), and followed by several studies in March-April 2011 (Wagiyo et al., 2012), and November 2013, October 2015, April, August, September and November 2017 and February, March, April, and May 2018 (present study). The compilation of the data source is shown in Table 1.

\section{Sampling method}

Different sampling methods in each survey, tuna larvae were sampled with horizontal towing that discrete depth layers, from 0-100 m, 100-300, and 0-500 m (Soewito and Schalk, 1990), vertical and horizontal towing in $150 \mathrm{~m}$ (Wagiyo et al., 2012), oblique, diagonal, and step tow, net towed horizontally and obliquely (ladderlike), in $100 \mathrm{~m}$ and $300 \mathrm{~m}$ (present study).

Samples were preserved directly after capture on either $70 \%$ alcohol or $4 \%$ buffered (sodium tetraborate) formalin (Soewito and Schalk, 1990), 4\% formalin (Wagiyo et al., 2012), and $10 \%$ buffered (sea water) formalin (present study).

\section{Data analysis}

Tuna larvae were observed under a stereomicroscope (Nikon SMZ1270i) and identified morphologically into the lowest possible taxon using available literatures (Nishikawa and Rimmer, 1987; Neira et al., 1998; Leis and Carson-Ewart, 2004; Kendall, 2011; Izumi et al., 2014). Larva stages is classified in 5 stages, yolk sac, pre flexion, flexion, post flexion, and juvenile, (Kendall, et al., 1984).

\section{RESULTS}

Total of 143 stations have been sampled from those surveys and tuna larvae found in 57 stations (Figure 1 and Table 1). Some of survey locations found tuna larvae outside the conservation area determined by (Kementerian Perikanan dan Kelautan, 2015) MMAF Regulation No 42015 which geographically describes within $4^{\circ} 0^{\prime} 0^{\prime \prime} \mathrm{S}$ - 
$6^{\circ} 0^{\prime} 0^{\prime \prime S} \quad 126^{\circ} 0^{\prime} 0 " \mathrm{E}-132^{\circ} 0^{\prime} 0 " \mathrm{E}$. Seasonal observation showed that tuna larvae abundance on February-April was higher than August-November (Table 2).

Our data from surveys in November 2013 and October 2015 could not be converted to abundance unit due to limited information available (the volume of filtered waters was unknown). The average standard body length (SL) of larvae tuna was around 7.36 \pm $0.33 \mathrm{~mm}$. Generally, tuna larvae found in the Banda Sea were in the pre-flexion, flexion, and post-flexion stage (Figure 2). Meanwhile, tuna larvae in pre-flexion stage found in the nearshore area.

Survey on November 2013 found larvae tuna in 3 phases were pre flexion, flexion, and post flexion, on October 2015 larvae tuna in pre flexion phase was absence, and on February 2018 only pre flexion larvae was presence. The development stages of tuna larvae shown in Figure 3.

\section{DISCUSSION}

Distribution of tuna larvae depend on specific species, Thunnus thynnus, $T$. atlanticus and T. obesus mostly distributed on offshore waters (Koched et al., 2016, Cornic et al., 2018), T. albacares distribution mostly in offshore yet it can be found in nearshore (river plume) also (Lang et al., 1994, Tzeng et al., 1997, Cornic et al., 2018) Auxis rochei and the Euthynnus alletteratus, E. affinis larvae distribute mostly in nearshore (Tzeng et al., 1997, Koched et al., 2016, Al-Abri et al., 2017), and $T$. alalunga larvae showed a very scattered distribution (Koched et al., 2016). Some species mainly found in shallower waters between 50 and $400 \mathrm{~m}$, such as $A$. rochei, E. alletteratus, E. affinis, and Katsuwonus pelamis (Soewito and Schalk, 1990, Boehlert et al., 1992, Tzeng et al., 1997, Koched et al., 2016, Al-Abri et al., 2017), density of larvae decreasing by increasing depth (Soewito and Schalk, 1990, Boehlert et al., 1992). And some species prefer in deeper waters between 400 and 800 $\mathrm{m}$, such as T. thynnus (Koched et al., 2016).
Distribution and abundance of tuna larvae were influenced by physical and chemical conditions of the water mass notably sea surface temperature and salinity (Cornic et al., 2018). Tuna larvae higher abundance in waters with surface temperature, between 24 and $25^{\circ} \mathrm{C}$ (warm waters) (García et al., 2005, Koched et al., 2016, Cornic et al., 2018) Tuna larvae were most abundant at intermediate salinities, with values not exceeding 37.5 (Lang et al., 1994, Koched et al., 2016, Cornic et al., 2018).

Tuna larvae found in April to August (Tzeng et al., 1997, Koched et al., 2016, AlAbri et al., 2017, Cornic et al., 2018) depending on specific species, larvae of Auxis sp. found in May to August, Thunnus $s p$. April (Tzeng et al., 1997). June and July to correspond with the spawning period of several tunas in the Gulf of Mexico. With larvae were present higher for T. atlanticus and $T$. obesus in July and for T. albacares and T. thynnus larvae in June (Cornic et al., 2018). Meanwhile (Lang et al., 1994) suggested that $T$. albacares spawning dates from 13-24 July and 22-31 August. In the southeast monsoon (August) about $60 \%$ of the larvae were from oceanic taxa, and only $30 \%$ in the northwest monsoon (Feb/March) (Soewito and Schalk, 1990). Auxis sp. larvae that found in May to August on whole development stage (yolk sac, pre flexion, flexion, and post flexion) and Thunnus sp. larvae that found in April on Pre flexion phase (Tzeng et al., 1997).

The development stage of larvae is also important in evaluating tuna conservation. We can estimate larval ages from the development stage of larvae, whereas proper method for estimates larval ages are using otolith microstructure, but we can use results of previous study on larval age estimates. Sagittal otolith microstructure was used to estimated larval ages (Lang et al., 1994). The estimate of larval ages was used to backcalculate of spawning periods.

Average body length (BL) of T. thynnus larvae was $2.83 \mathrm{~mm}$ (newly hatched), 3.54 $\mathrm{mm}$ (1 day old, yolk sac larva), $3.81 \mathrm{~mm}$ (3 day old, pre flexion larva), $4.02 \mathrm{~mm}$ (4 day old, pre flexion larva), $5.34 \mathrm{~mm}$ (7 day old, flexion larva), $7.23 \mathrm{~mm}$ (15 day old, post 
flexion larva), $8.64 \mathrm{~mm}$ (20 day old, post flexion larva), and $13.55 \mathrm{~mm}$ (25 day old, juvenile) (Miyashita et al., 2001, García et al., 2006). Auxis rochei between 2 and 3.5 $\mathrm{mm}$ (2 to 4 days old) (Laiz-Carrión et al., 2013), E. alletteratus between 2 and $3.5 \mathrm{~mm}$ (1 to 3 days old) (Allman and Grimes, 1998), S. sarda smaller than $3.5 \mathrm{~mm}$ and between 6.6 and $7.5 \mathrm{~mm}$ (about 1 day old and 5 to 7 days old) (García et al., 2006, Sarropoulou et al., 2014). T. alalunga smaller than 3.5 $\mathrm{mm}$ and between 4.6 and $5.5 \mathrm{~mm}$ (about one day and 10 to 14 days old) (García et al., 2006, Sarropoulou et al., 2014).

\section{CONCLUSION}

This study shows that tuna larvae were found in 57 stations surrounding the Banda Sea. The larvae dispersal indicate that tuna larvae distributed within and beyond the conservation zone, as mentioned in MMAF Regulation No 4 2015. This phenomenon provides an understanding that territorial restriction is part of the area where larvae are present. Therefore, we suggest to carry out more frequent observations and provide better source of reliable data on abundance estimation and distribution tuna larvae to improve the existing conservation zone of tropical tuna in the Banda Sea. Body length (SL) of larvae tuna was $7.36 \pm 0.33 \mathrm{~mm}$. Tuna larvae found in the Banda Sea were in the pre-flexion, flexion, and post-flexion stage. We concluded that this result strongly supported the hypothesis that tuna might spawn in the Banda Sea within certain period. Therefore, some more studies on tuna larvae should be conducted regularly to support fisheries policy that the Banda Sea is one of the important tuna conservation areas in the country.

\section{REFERENCES}

Al-Abri, N. M., A. Piontko, S., Rabbaniha, M., Al-Hashmi, K., and Chesalina, T. (2017). Taxonomic Composition and Seasonal Changes of Fish Larvae
Assemblages in Coastal Waters of Muscat, Sea of Oman (2013-2015). Journal of Fisheries and Aquatic Science, 12(2), 95-105. https://doi.org/10.3923/jfas.2017.95.1 05

Allman, R. J., and Grimes, C. B. (1998). Growth and mortality of little tunny (Euthynnus alletteratus) larvae off the Mississippi River plume and Panama City, Florida. Bulletin of Marine Science, 62(1), 189-197.

Boehlert, G. W., Watson, W., and Sun, L. C. (1992). Horizontal and vertical distributions of larval fishes around an isolated oceanic island in the tropical Pacific. Deep-Sea Research Part A, Oceanographic Research Papers, 39(3-4), 439-466. https://doi.org/10.1016/01980149(92)90082-5

Cornic, M., Smith, B. L., Kitchens, L. L., Alvarado Bremer, J. R., and Rooker, J. R. (2018). Abundance and habitat associations of tuna larvae in the surface water of the Gulf of Mexico. Hydrobiologia, $\quad 806(1), \quad 29-46$. https://doi.org/10.1007/s10750-0173330-0

García, A., Alemany, F., Velez-Belchí, P., Jurado, J. L. L., Cortés, D., Serna, J. M. D. La, Pola, C. G., Rodríguez, J. M., Jansá, J., and Ramírez, T. (2005). Characterization of the Bluefin Tuna Spawning Habitat Off the Balearic Archipelago in Relation To Key Hydrographic. Collected Volume of Scientific Papers ICCAT, 58(2), 535549.

García, A., Cortés, D., Ramírez, T., FehriBedoui, R., Alemany, F., Rodríguez, J. M., Carpena, Á., and Álvarez, J. P. (2006). First data on growth and nucleic acid and protein content of field-captured Mediterranean bluefin (Thunnus thynnus) and albacore (Thunnus alalunga) tuna larvae: a comparative study. Scientia Marina, $70(\mathrm{~S} 2)$, 67-78. https://doi.org/10.3989/scimar.2006.7 0s267

Hitchman, S. M., Reyns, N. B., and Thompson, A. R. (2012). Larvae 
define spawning habitat of bocaccio rockfish Sebastes paucispinis within and around a large Southern California marine reserve. Marine Ecology Progress Series, 465(July), 227-242. https://doi.org/10.3354/meps09926

Izumi, K., Tomoji, I., Akio, H., Shigeo, T., Yosuke, O., and Satoshi, M. (2014). 日本座稚魚図鑑 $=A n$ atlas of early stage fishes in Japan: 2nd ed. (Kanagawa: Tokai University Press). pp 977- 1641.

Kendall, A. W., Jr., Ahlstrom, E. H., and Moser, H. G. (1984). Early Life History Stages of Fishes and Their Characters. COHEN: Ontogeny, Systematics. Phylogeny. 11-22.

Kendall, A. W., Jr. (2011). Identification of eggs and larvae of marine fishes. (Kanagawa: Tokai University Press). p 379.

Koched, W., Alemany, F., Rimel, B., and Hattour, A. (2016). Characterization of the spawning area of tuna species on the northern Tunisian coasts. Scientia Marina, $\quad$ 80(2), 187-198. https://doi.org/10.3989/scimar.04332. $27 \mathrm{a}$

Laiz-Carrión, R., Quintanilla, J. M., Torres, A. P., Alemany, F., and García, A. (2013). Hydrographic patterns conditioning variable trophic pathways and early life dynamics of bullet tuna Auxis rochei larvae in the Balearic Sea. Marine Ecology Progress Series, 475(December 2014), 203-212. https://doi.org/10.3354/meps 10108

Lang, K. L., Grimes, C. B., and Shaw, R. F. (1994). Variations in the age and growth of yellowfin tuna larvae, Thunnus albacares, collected about the Mississippi River plume. Environmental Biology of Fishes, 39(3), 259-270. https://doi.org/10.1007/BF00005128

Lehodey, P., Senina, I., Wibawa, T. A., Titaud, O., Calmettes, B., Conchon, A., Tranchant, B., and Gaspar, P. (2018). Operational modelling of bigeye tuna (Thunnus obesus) spatial dynamics in the Indonesian region. Marine
Pollution Bulletin, 131(August 2017), 19-32.

https://doi.org/10.1016/j.marpolbul.20 17.08.020

Leis, J. M., and Carson-Ewart. (2004). The larvae of Indo-Pacific coastal fishes: an identification guide to marine fish larvae 2nd ed. (Leiden; Boston: Brill). $\mathrm{p}$ 850.

López-Sanz, À., Vert, N., Zabala, M., and Sabatés, A. (2009). Small-scale distribution of fish larvae around the Medes Islands marine protected area (NW Mediterranean). Journal of Plankton Research, 31(7), 763-775. https://doi.org/10.1093/plankt/fbp024

Menteri Perikanan dan Kelautan. (2015). Peraturan Menteri Kelautan Dan Perikanan Republik Indonesia.

Miyashita, S., Sawada, Y., Okada, T., Murata, O., and Kumai, H. (2001). Morphological development and growth of laboratory-reared larval and juvenile Thunnus thynnus (Pisces: Scombridae). Fishery Bulletin, 99(4), 601-616.

Neira, F. J., Miskiewicz, A. G., and Trnski, T. (1998) Larvae of temperate Australian fishes: laboratory guide for larval fish identification. (Nedlands: University of Western Australia Press). p 474.

Nishikawa, Y., and Rimmer, D. W. (1987) Identification of larval tunas, billfishes and other scombroid fishes (Suborder Scombroidei): an illustrated guide. Series report Commonwealth Scientific and Industrial Research Organisation (Australia) Marine Laboratories no. 186 (Melbourne: CSIRO). p 25.

Sarropoulou, E., Moghadam, H. K., Papandroulakis, N., De La Gándara, F., Garcia, A. O., and Makridis, P. (2014). The Atlantic bonito (Sarda sarda, Bloch 1793) transcriptome and detection of differential expression during larvae development. PLoS 
ONE,

9(2),

$7-13$.

https://doi.org/10.1371/journal.pone.0 087744

Satrioajie, W. N., Suyadi, Syahailatua, A., and Wouthuyzen, S. (2018). The importance of the Banda Sea for tuna conservation area: A review of studies on the biology and the ecology of tuna. In IOP Conference Series: Earth and Environmental Science (Vol. 184). https://doi.org/10.1088/17551315/184/1/012004

Soewito, and Schalk, P. H. (1990). Spatial and seasonal patterns in fish larvae distribution in the Banda Sea (Indonesia). Netherlands Journal of Sea Research, 25(4), 591-600. https://doi.org/10.1016/00777579(90)90081-Q

Sunoko, R., and Huang, H. W. (2014). Indonesia tuna fisheries development and future strategy. Marine Policy, 43, 174-183.

https://doi.org/10.1016/j.marpol.2013. 05.011

Syamsudin, F., van Aken, H. M., and
Kaneko, A. (2010). Annual variation of the southern boundary current in the Banda Sea. Dynamics of Atmospheres and Oceans, 50(2), 129-139. https://doi.org/10.1016/j.dynatmoce.2 009.12.005

Tapilatu, Y., Sabandar, A. H., Salawane, V., and Syahailatua, A. (2018). Fish larval composition and distribution assessment in the northern waters of Ambon Island. In IOP Conference Series: Earth and Environmental Science (Vol. 184, p. 12008). https://doi.org/10.1088/17551315/184/1/012008

Tzeng, W. N., Wang, Y. T., and Chern, Y. T. (1997). Species composition and distribution of fish larvae in Yenliao Bay, northeastern Taiwan. Zoological Studies, 36(2), 146-158.

Wagiyo, K., Chodrijah, U., and Restiangsih, Y. H. (2012). Kelimpahan dan sebaran larva scombridae di perairan laut banda. (A. Suman, Wudianto, \& B. Sumiono, Eds.). IPB Press. 


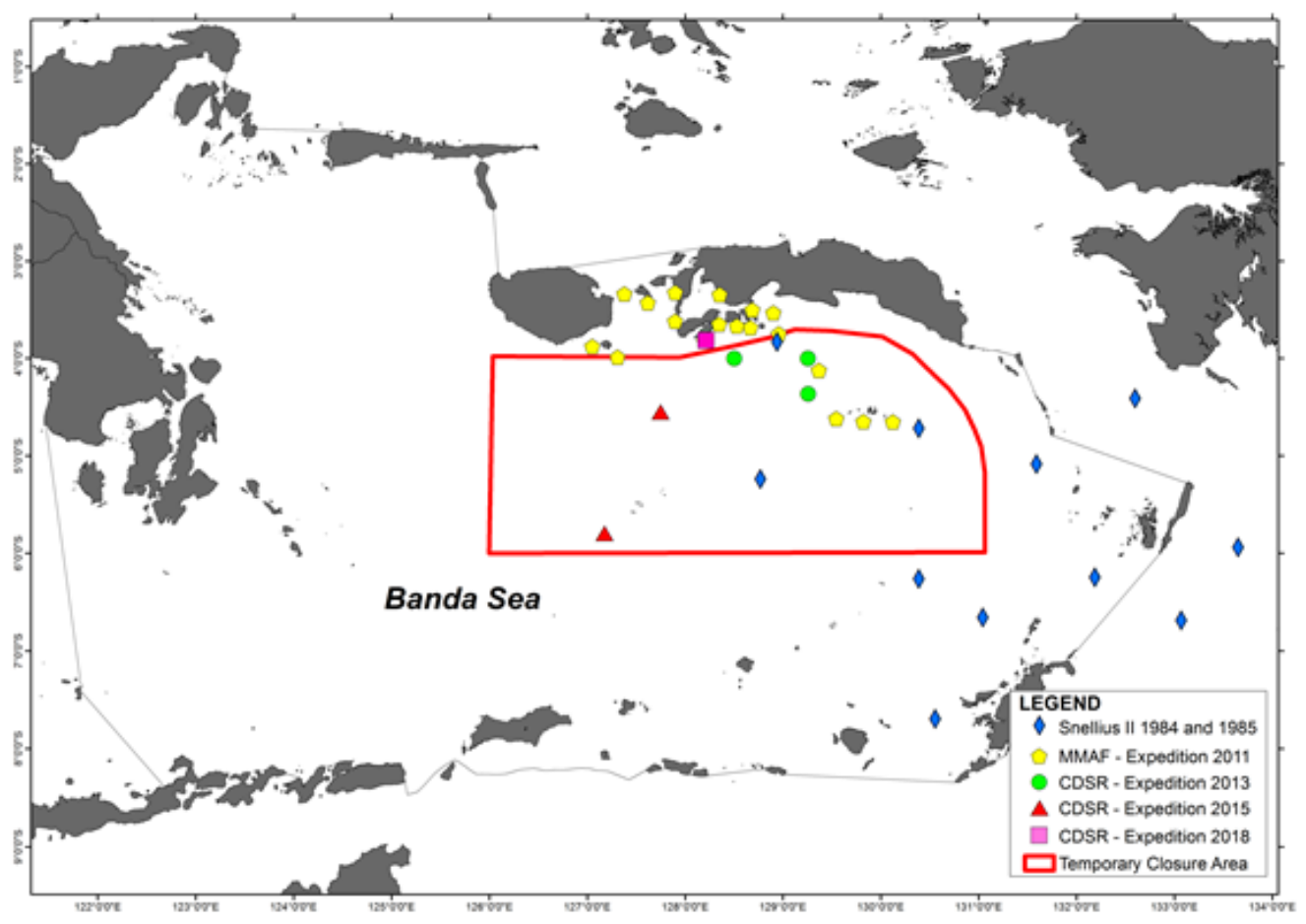

Figure 1. Survey locations which tuna larvae were collected.

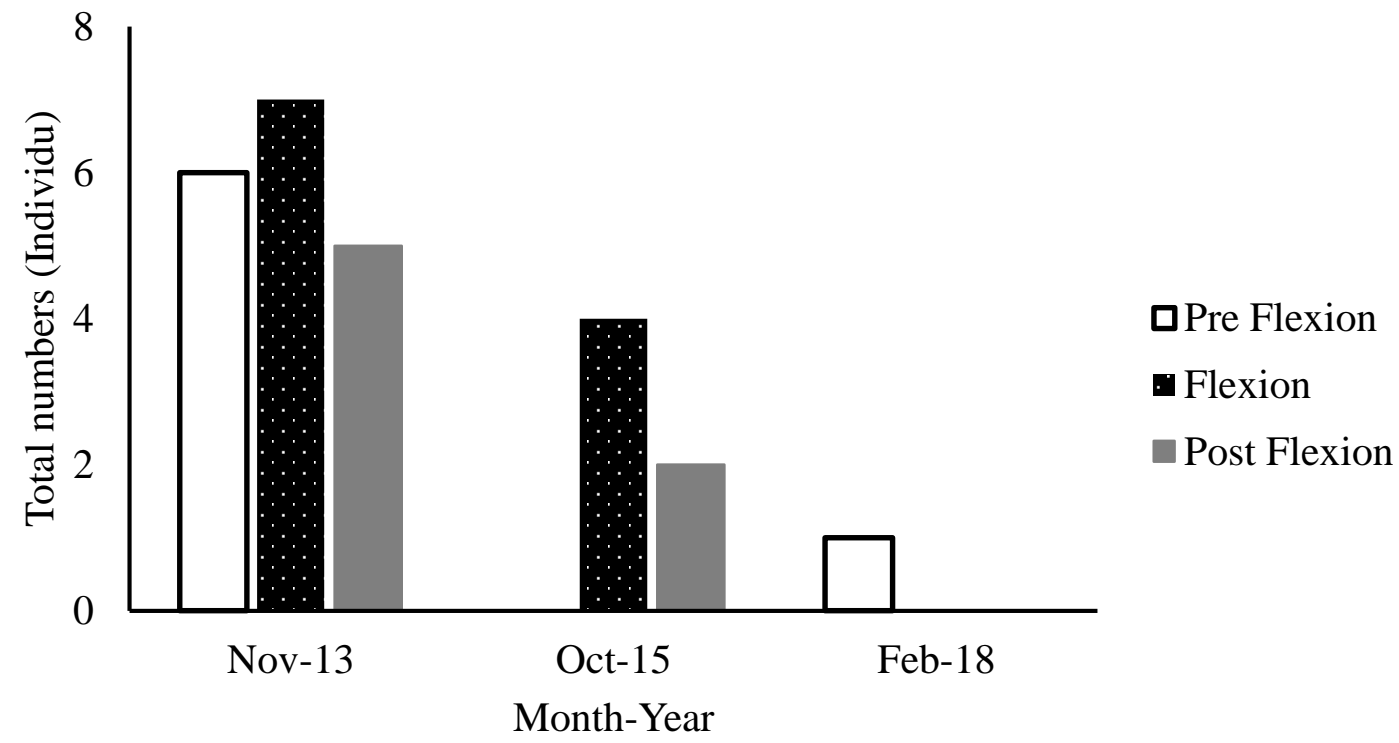

Figure 2. Tuna larvae phase found in surveys. 


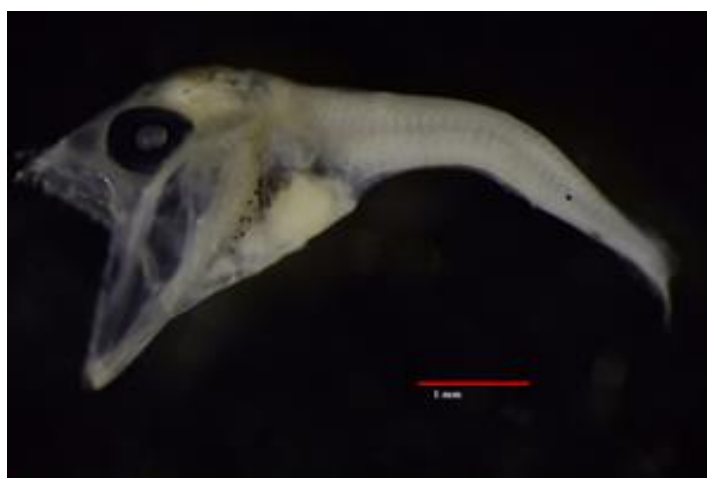

(a)

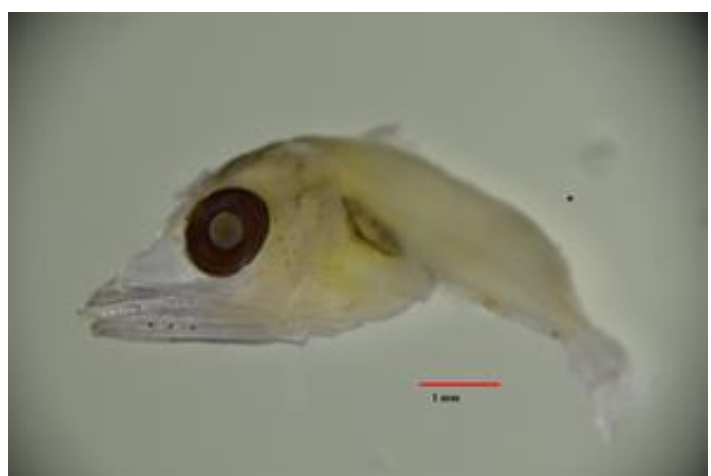

(b)

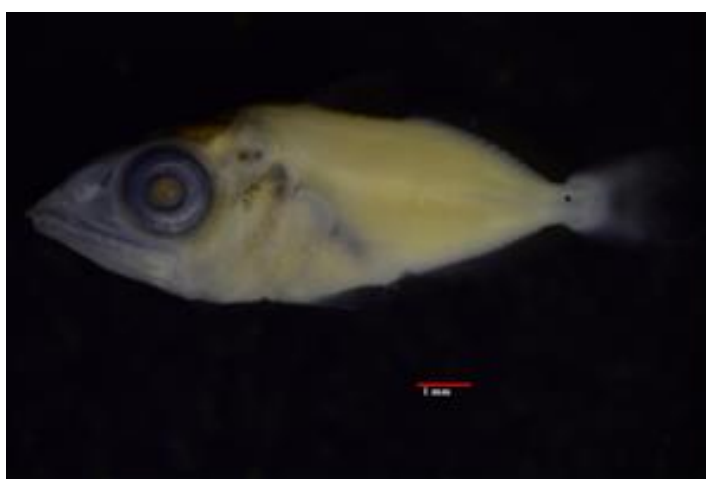

(c)

Figure 3. Development stage of tuna larvae (a) pre flexion phase (c) flexion phase and (c) post flexion phase. Scale bar: $1 \mathrm{~mm}$.

Sources: personal documentations 
Mar. Res. Indonesia Vol.44, No.2, 2019: 82-90

Table 1. Compilation of the data source used in the study with particular interest on tuna larva

\begin{tabular}{lccc}
\hline Survey periods & Station number & Sampling gear & Sources \\
\hline August 1984 & 16 & RMT $^{\mathrm{a}}$ & (Soewito and Schalk, 1990) \\
February-March 1985 & 16 & RMT & (Wagiyo et al., 2012) \\
March-April 2011 & 18 & Bongo net & \\
November 2013 & 4 & IKMT $^{\mathrm{b}}$ & RCDS \\
October 2015 & 2 & IKMT & \\
February 18 & 1 & Bongo net & \\
\hline
\end{tabular}

(a) Rectangular midwater trawl, (b) Isaacs Kidd Midwater Trawl (IKMT)

Table 2. Abundance of tuna larvae in each survey

\begin{tabular}{cccc}
\hline Time survey & Abundance $\left(\right.$ larvae. $\left.\mathrm{m}^{-3}\right)$ & Depth $(\mathrm{m})$ & Authors \\
\hline August 1984 & 0.003 & $0-100$ & (Soewito and Schalk, 1990) \\
February-March 1985 & 0.067 & $0-100$ & \\
March-April 2011 & 0.222 & $0-150$ & (Wagiyo et al., 2012) \\
November 2013 & $21^{*}$ & $0-300$ & RCDS \\
October 2015 & $7^{*}$ & $0-300$ & \\
February 2018 & 0.018 & $0-100$ & \\
\hline
\end{tabular}

Remark: * number of larvae (not abundance), because the volume of filtered waters was unknown 